\title{
Scientific drilling workshop on the Weihe Basin Drilling Project (WBDP): Cenozoic tectonic-monsoon interactions
}

\author{
Zhisheng An ${ }^{1,2}$, Peizhen Zhang ${ }^{3}$, Hendrik Vogel ${ }^{4}$, Yougui Song ${ }^{1,2}$, John Dodson $^{1,5}$, Thomas Wiersberg ${ }^{6}$, \\ Xijie Feng ${ }^{7}$, Huayu $\mathrm{Lu}^{8}, \mathrm{Li} \mathrm{Ai}{ }^{1}$, and Youbin $\mathrm{Sun}^{1,2}$ \\ ${ }^{1}$ State Key Laboratory of Loess and Quaternary Geology, Institute of Earth Environment, \\ Chinese Academy of Sciences, Xi'an 710061, China \\ ${ }^{2}$ CAS Center for Excellence in Quaternary Science and Global Change, Xi' an 710061, China \\ ${ }^{3}$ School of Earth Sciences and Engineering, Sun Yat-Sen University, Guangzhou 510275, China \\ ${ }^{4}$ Institute of Geological Sciences \& Oeschger Centre for Climate Change Research, \\ University of Bern, 3012 Bern, Switzerland \\ ${ }^{5}$ School of Earth, Atmospheric and Environmental Sciences, University of Wollongong, \\ Wollongong, NSW 2522, Australia \\ ${ }^{6}$ GFZ German Research Centre for Geosciences, 14473 Potsdam, Germany \\ ${ }^{7}$ Earthquake Administration of Shaanxi Province, Xi' an 710068, China \\ ${ }^{8}$ School of Geography and Ocean Science, Nanjing University, Nanjing 210023, China
}

Correspondence: Zhisheng An (anzs@loess.llqg.ac.cn)

Received: 1 September 2020 - Revised: 27 October 2020 - Accepted: 2 November 2020 - Published: 1 December 2020

\begin{abstract}
The Weihe Basin, enclosed by the Chinese Loess Plateau to the north and the Qinling Mountains to the south, is an outstanding, world-class continental site for obtaining high-resolution multi-proxy records that reflect environmental changes spanning most of the Cenozoic. Previous geophysical and sedimentary studies indicate that the basin hosts $6000-8000 \mathrm{~m}$ thick fluvial-lacustrine sedimentary successions spanning the Eocene to Holocene. This sedimentary record provides an excellent and unique archive to decipher long-term tectonicclimate interactions related to the uplift of the Tibetan Plateau, the onset/evolution of the Asian monsoon, and the development of the biogeography of East Asia. Owing to its location at the interface of the opposing westerly and Asian monsoon circulation systems, the Weihe Basin also holds enormous promise for providing a record of changes in these circulation systems in response to very different boundary conditions since the Eocene. To develop an international scientific drilling programme in the Weihe Basin, the Institute of Earth Environment, Chinese Academy of Sciences, organized a dedicated workshop with 55 participants from eight countries. The workshop was held in Xi'an, China, from 15 to 18 October 2019. Workshop participants conceived the key scientific objectives of the envisaged Weihe Basin Drilling Project (WBDP) and discussed technical and logistical aspects as well as the scope of the scientific collaboration in preparation for a full drilling proposal for submission to the International Continental Scientific Drilling Program (ICDP). Workshop participants mutually agreed to design a two-phase scientific drilling programme that will in a first phase target the upper $3000 \mathrm{~m}$ and in a second phase the entire up to $7500 \mathrm{~m}$ thick sedimentary infill of the basin. For the purpose of the $7500 \mathrm{~m}$ deep borehole, the world's only drill rig for ultra-deep scientific drilling on land, Crust 1, which previously recovered the entire continental Cretaceous sediments in the Songliao Basin, will be deployed in the WBDP.
\end{abstract}




\section{Introduction}

The Earth has experienced remarkable climate and environmental changes during the last 65 million years. The most prominent characteristic of global Cenozoic climate evolution, primarily inferred by marine benthic oxygen isotope records, is a stepwise cooling since the Eocene from a hot "greenhouse" to a cold "icehouse" Earth, associated with the initiation and expansion of the bipolar ice sheets (Zachos et al., 2001; Westerhod et al., 2020). Against the backdrop of global cooling during the Cenozoic, the salient trend in Asia was the development of the coupled monsoon-arid environment system at tectonic timescales, which was largely driven by a reorganization of atmospheric circulation systems in response to the India-Asia collision and the subsequent uplift of the Tibetan Plateau, and the global cooling (Kutzbach et al., 1993; Ramstein et al., 1997, An et al., 2001; An, 2014; Lu et al., 2010). To date a continuous Cenozoic record capturing both the effects of global climate change and regional tectonics on Asian climate has yet to be recovered. Such a record is critical for enhancing our knowledge about when and how the Asian monsoon originated while at the same time enabling assessment of the mechanism of tectonic-climate interactions through the entire Cenozoic era. It will also provide information on how the Asian monsoon evolution influenced the development of Asian ecosystems up to the present day.

Being a critical and powerful approach in the geosciences, scientific drilling under the umbrella of the ICDP has been very successful over recent decades by providing critical materials from various key sites and pushing forward the frontiers of Earth sciences. Over the last 2 decades, ICDP has funded many drilling projects to address changes in the Earth's climate and ecosystem in the geological past. However, few of these have targeted continuous sedimentary strata dating beyond the Pleistocene. In East Asia, previous ICDP drilling projects have focused on the late Jurassic to Paleogene, mostly Cretaceous, Songliao Basin, as well as late Quaternary strata (Lake Qinghai, Fig. 1). To date, there has been a paucity of high-quality continental records for the intervening periods that have shaped the modern face of the Earth.

Due to the stepwise growth of the northern Tibetan Plateau during the late Cenozoic, a series of tectonic basins were developed in the surrounding areas, such as the Tarim Basin (Sun et al., 2009; Liu et al., 2014), Qaidam Basin (Yin et al., 2008; Zhang et al., 2012), Xining Basin (Fang et al., 2019), Linxia Basin (Fang et al., 2003), and Lanzhou Basin (Yue et al., 2001). Thick deposits of these basins provide direct evidence of a Cenozoic drying history of inland Asia (Dupont-Nivet et al., 2007; Wang et al., 2012; Liu et al., 2014; Li et al., 2014). Compared with sedimentary records of these inland basins, the Weihe Basin is tectonically related to the long-range effects of the uplift of the Tibetan Plateau, but the sedimentary records are more sensitive to monsoonal climate changes (Lu et al., 2018). Therefore, investigation into the sedimentary records in the Weihe Basin will deepen our understanding regarding when the coupled Asian monsoon-arid environmental system was formed and how the monsoon climate evolved in response to Tibetan Plateau growth and global cooling. The Weihe Basin, with its $6000-8000 \mathrm{~m}$ thick uninterrupted fluvial-lacustrine sedimentary succession spanning the Eocene to the present (Jia et al., 1966; Liu et al., 1960; Chen et al., 1977; RGS, 1989; Wang et al., 2013; Lu et al., 2018), is the most continuous continental archive of Cenozoic climate evolution in East Asia. Because of its unique geographical location, the region around the Weihe Basin is significantly affected by the Asian monsoon, which is a major component of global atmospheric circulation (An et al., 2015). Apart from its enormous promise for Cenozoic paleoclimate research, the Weihe Basin has also preserved evidence of the earliest appearance of hominins outside Africa (Maslin et al., 2015; Potts, 2013), known as the cradle of ancient Chinese civilization (An and Ho, 1989; Zhuo et al., 2016; Zhu et al., 2018).

Changes in the Earth's climate system on global and regional scales are attributed to both natural factors and human activities (IPCC, 2001). What we learn from the geological past about natural change is key to predicting Earth's future under the influence of ongoing anthropogenic effects. It is therefore important to understand the response of largescale atmospheric circulations and ecosystems under analogous greenhouse climate conditions of the Cenozoic (Zachos et al., 2001; Haywood et al., 2016; Zhang et al., 2013). Owing to its continuity in sediment deposition, the Weihe Basin is ideally suited to producing a critically important record capable of elucidating the effect of global-scale climate and regional-scale tectonics on the evolution of the major atmospheric circulation systems in Asia and the response of eco-environmental systems to high atmospheric greenhouse gas concentrations during several critical warm periods (e.g. Kutzbach and Behling, 2004; Ji et al., 2018; Zhao et al., 2020).

Being located at the boundary between subtropical forest and the temperate vegetation zone (http://www.ecosystem. csdb.cn, last access: 18 November 2020), the Weihe Basin also offers the opportunity to depict changes in the timetransgressive evolution of Angiosperms and the expansion of grasses using the $\mathrm{C}_{4}$ photosynthetic pathway and their links to Cenozoic tectonic-climate interactions (Wang et al., 2019). Similarly to the surface ecosystems, subsurface ecosystems also involve complex interactions between life and the environment. While the limits of life at depths in the marine sediment record are constantly being revised (Schippers et al., 2005; Flemming and Wuertz, 2019), similar studies from continental settings have been limited to date. Thick sedimentary strata of the Weihe Basin are an ideal complement that will help to characterize the limits of life as well as its metabolic pathways and products at depth in a continental setting, a goal that has so far not been targeted. Direct obser- 


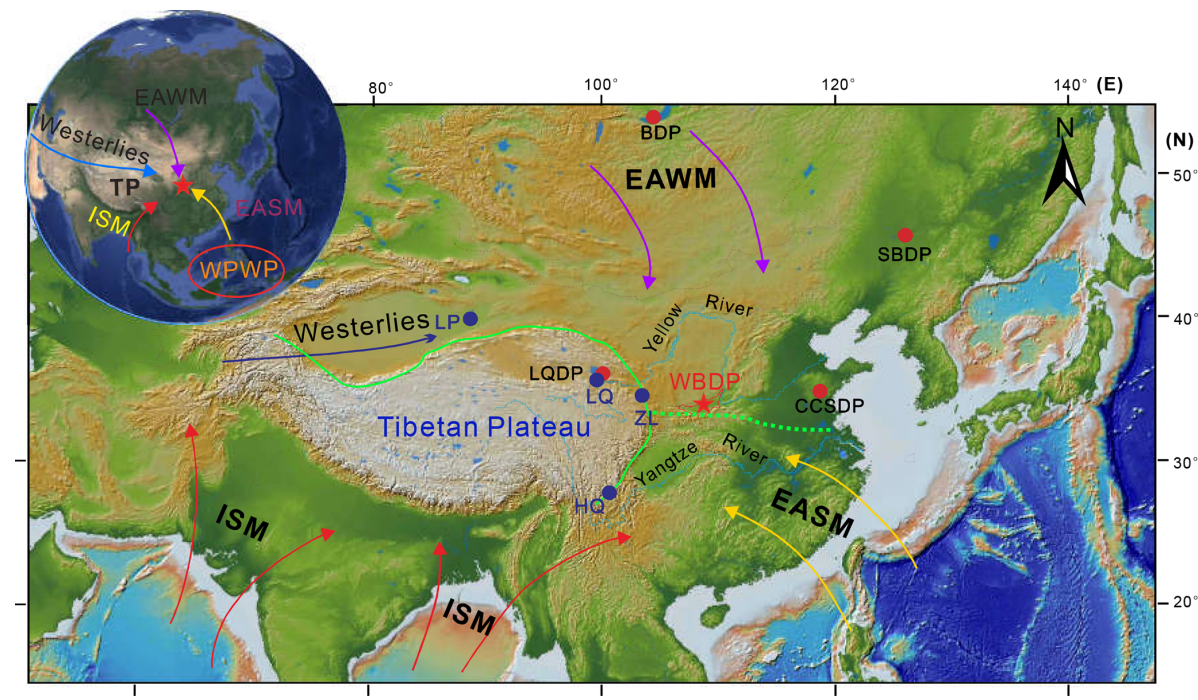

Figure 1. Atmospheric circulation systems in East Asia and locations of previous ICDP (red dots) and CESD (blue dots, Chinese Environmental Science Drilling) drilling sites and the proposed site of the Weihe Basin Drilling Project (WBDP; red star). BDP: Lake Baikal; SBDP: Songliao Basin; LQDP: Lake Qinghai; LP: Lop Nur; LQ: Lake Qinghai; ZL: Zhuanglang; and HQ: Heqing Paleolake. ISM: Indian Summer Monsoon; EASM: East Asian Summer Monsoon; EAWM: East Asian Winter Monsoon; and WPWP: West Pacific Warm Pool.

vations and measurements in a deep borehole will offer great promise for depicting how deep Earth ecosystems respond to an extreme environment.

The formation and evolution of the Weihe Basin are closely related to the long-range effects of the uplift of the Himalayan-Tibetan Plateau, growth of the Qinling Mountains, as well as the Ordos block deformation (Zhang et al., 1995, 2002; Shi et al., 2008; Liu et al., 2013; Shi et al., 2019). The thick sediment package retains a record of tens of millions of years of regional tectonic evolution with information continuously stored as denudation products in the Weihe Basin. The envisaged WBDP will provide a unique opportunity to closely capture mountain-building processes of the Qinling Mountains, the landform dividing northern and southern China geographically, biogeographically, and climatically, through proximal denudation products delivered by rivers draining the mountain range and deposited in the basin. Owing to its eastern location, the sedimentary record of the Weihe Basin also holds promise for identifying potential imprints of major uplift and exhumation events of the Tibetan Plateau, which played significant roles in the formation and evolution of the Asian monsoon-arid environmental systems (An et al., 2001, 2015).

\section{Site description}

The Weihe Basin is located in central China and extends $400 \mathrm{~km}$ from $\mathrm{E}$ to $\mathrm{W}\left(107-110^{\circ} 35^{\prime} \mathrm{E}\right)$ and $\sim 30-80 \mathrm{~km}$ along its $\mathrm{N}-\mathrm{S}$ axis $\left(34-35^{\circ} 40^{\prime} \mathrm{N}\right)$, covering an area of about $20000 \mathrm{~km}^{2}$ at an average elevation of $400 \mathrm{~m}$ above sea level (a.s.1.) (Fig. 2a). The Qinling Mountains to the south reach elevations of 2000-3700 m a.s.l., and the Weihe North Mountains to the north are at $\sim 900-1300 \mathrm{~m}$ a.s.l. The overall terrain of the Weihe Basin is inclined towards the east. The bedrock composition of the Weihe Basin is complex, with Paleozoic limestone in the northern basin and ArcheanProterozoic metamorphics and Mesozoic plutonics in the southern basin (Shi et al., 2008; Lin et al., 2015; Song et al., 2018). Climatologically, the area is located at the boundary between the subtropical monsoon and temperate monsoon areas, with rainfall being sourced primarily from the tropical Indo-Pacific oceans. Its annual average temperature is $\sim 12$ $14^{\circ}$, and the average annual precipitation is $\sim 500-700 \mathrm{~mm}$, with $55 \%$ of this precipitation falling during the summer monsoon-dominated season (June to September). The Weihe Basin is sensitive to changes in the Asian Monsoon (AM) circulation, characterized by seasonal shifts in wind direction between the cold and dry winter and the warm and humid summer. As an important component of the global climate system, the AM affects almost one-third of the world's population and is of major importance for regional socioeconomic and sustainable development.

Geophysical (reflection seismic and gravimetry) and borehole data suggest continuous subsidence for $>7000 \mathrm{~m}$ of sediment accommodation space in the two depocentres of the Weihe Basin (Chen et al., 1977; RGS, 1989; Xu et al., 2014; Liu et al., 2016; Li et al., 2016) (Fig. 2). Bio- and magneto-stratigraphy of outcrops and available drill cores indicates that sediments have accumulated continuously since the Eocene (e.g. Wang et al., 2013; Zhao et al., 2018; Lu et al., 2018). Lithologies consist mainly of fine-grained lacustrine sediments that are occasionally interspersed with somewhat coarser fluvial deposits (Chen et al., 1977; RGS, 
(a) $107^{\circ}$

$108^{\circ}$

$109^{\circ}$

$110^{\circ}$

$111^{\circ}(\mathrm{E})$

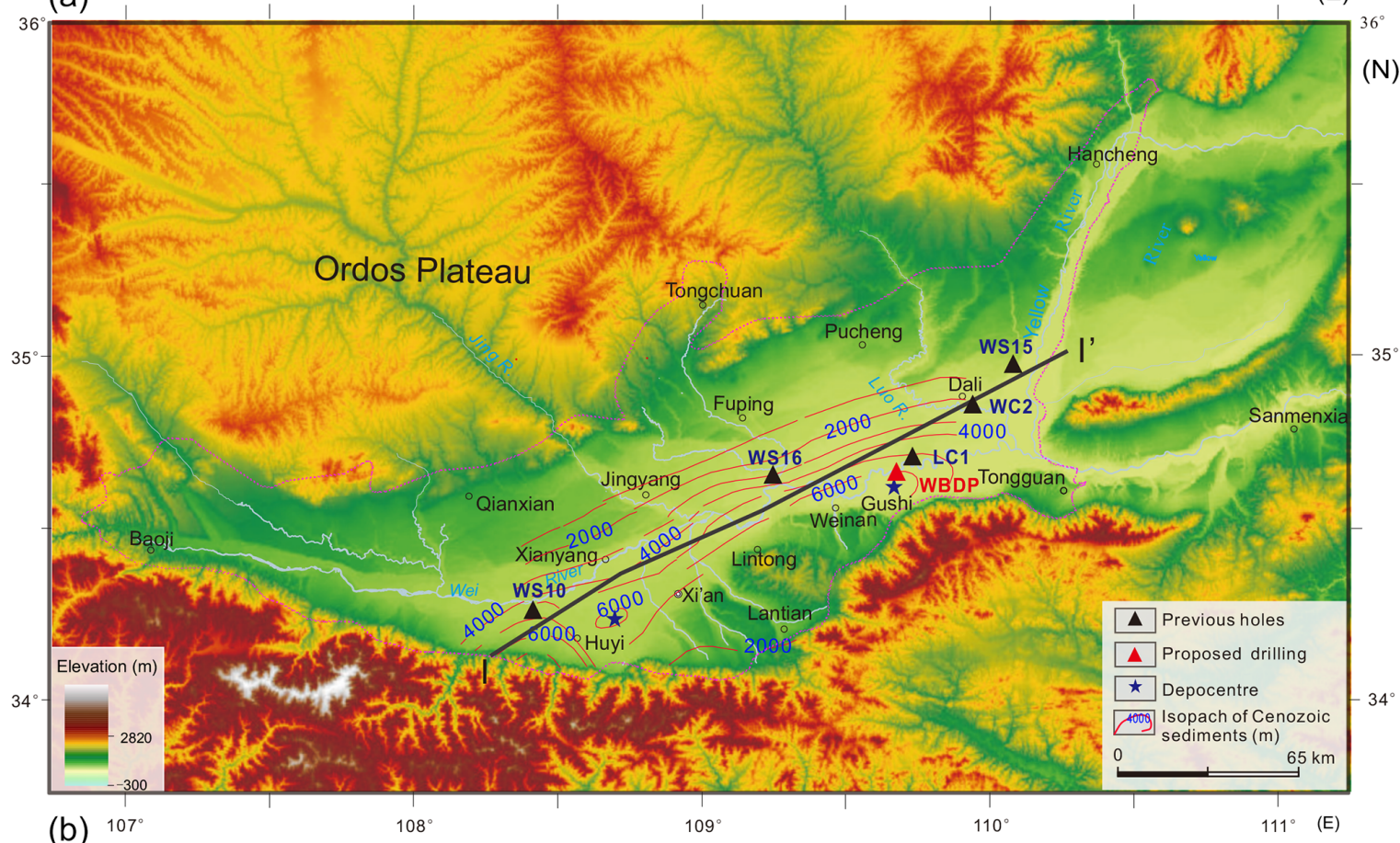

Elevation

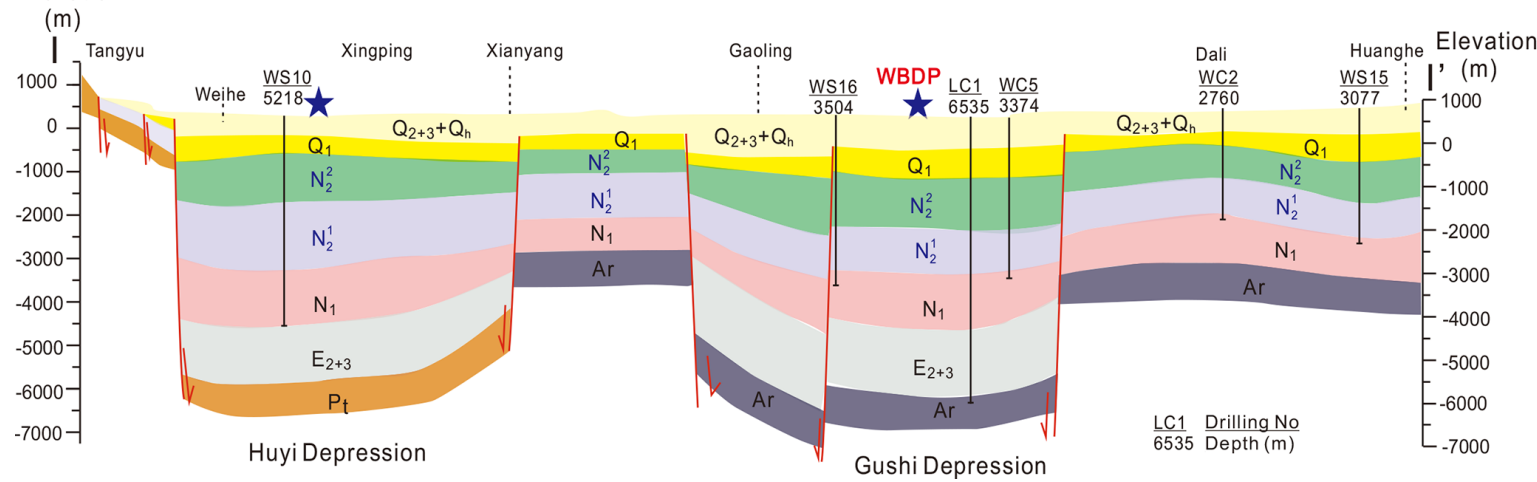

Figure 2. Isopach maps of Cenozoic sediments (a) and a stratigraphic cross section (b) through the Weihe Basin. Blue and red stars indicate the eastern and western depocentres.

1989; Lu et al., 2018; Liu et al., 2019). Recent investigations into outcrops in the forefront of the Li Shan and Qinling Mountains provide a preliminary framework of the Cenozoic basin stratigraphy and a glimpse into regional environmental changes (Wang et al., 2014; Lu et al., 2018). Unfortunately, these outcrops capture primarily proximal deposits composed of successions ranging from fluvial pebbles and sand layers to lacustrine silty clay deposits, providing only a general framework of Cenozoic depositional environments in the Weihe Basin (Wang et al., 2013). Due to the lack of temporal continuity, these deposits are not suitable for long-time high-resolution paleoclimatic reconstructions. Hence, the promising way to produce a continuous sedimentary record is through drilling in the depocentres of the Weihe Basin.

\section{Previous investigations}

Based on geophysical, tectonic, and geological evidence, there are three proposed formation mechanisms of the Weihe Basin, including the following: (1) the eastward extrusion of the Tibetan Plateau caused the extension of the Weihe Basin (Molnar and Tapponnier, 1975; Zhang et al., 1995), which is supported by mechanical simulation of indentation on plasticine models (Peltzer and Tapponnier, 1988); (2) continued Pacific-Eurasian collision in East Asia since the Mesozoic caused rifting in the Weihe Basin (Northrup et al., 1995; Ye et al., 1987); and (3) Cenozoic extension in the Weihe Basin resulted from the combined effects of the India-Asia Plate collision and subduction of the western Pacific Plate beneath the Asian Plate (Song et al., 2018). Provenance studies sug- 
gest that deposition in the Weihe Basin is largely controlled by the uplift of the Qinling Mountains (Dong et al., 2011; Meng, 2017; Liu et al., 2019; Zhang et al., 2012), implying that a basin-range structure was formed and co-evolved since the early Cenozoic.

Previous geological surveys and pilot boreholes throughout the Weihe Basin have revealed that the basin contains a continuous, rapidly accumulating sedimentary succession, with accumulation rates averaging $\sim 60-100 \mathrm{~cm} \mathrm{kyr}^{-1}$ in the depocentre for the last $50 \mathrm{Myr}$ (Chen et al., 1977; RGS, 1989; $\mathrm{Li}, 2018$ ). Numerous outcrops surrounding the Weihe Basin have been investigated in the past decades (e.g. Liu et al., 1960; Yue, 1989; Kaakinen et al., 2006; Wang et al., 2014; Lu et al., 2018; Wang et al., 2019; Zhao et al., 2020). Lithological and biostratigraphic investigations of exposed outcrops between Xi' an and Lantian suggest that the fluvial-lacustrine sequences during the Eocene to Miocene accumulated in the lower part, with the Red Clay and loess-paleosol sequences deposited in the upper part since the late Miocene (Lu et al., 2018, and references therein).

Since the 1990s, investigations into the depositional facies, stratigraphy, mammal fossil assemblages, carbonate isotopes, pollen, and phytolith assemblages of the sedimentary outcrops exposed in the southern margin of the Weihe Basin have revealed significant changes in the Cenozoic environmental characteristics of the region. For example, sedimentological and magnetostratigraphic results of the Duanjiapo Red Clay section, for the first time, revealed a major environmental shift around the latest Miocene (Zheng et al., 1992). This environmental change is also confirmed by a large-scale $\mathrm{C}_{4} / \mathrm{C}_{3}$ vegetation change inferred from the carbon isotope records of fossil teeth and soil carbonates in the loess-Red Clay sequence at Lantian (An et al., 2005; Passey et al., 2009) as well as in vertebrate fossils of the Bahe Formation (Kaakinen et al., 2006). Carbon isotope results from the Lantian and Weinan profiles show that $\mathrm{C}_{4}$ grasses may have been a dominant grassland component already starting at $\sim 11 \mathrm{Ma}$ and experienced further stepwise expansions during the Pliocene, thereby suggesting early aridification in Asia (Sun et al., 2012; Wang et al., 2019). Quantitative phytolith- and pollen-based reconstructions of mean annual precipitation indicate a decrease from 800-1673 to 443$900 \mathrm{~mm}$ during the Pliocene, implying an important role of global cooling in driving Asian monsoon evolution (Wang et al., 2019; Zhao et al., 2020). Based on available data from the outcrops and borehole, a review work suggests that the Asian monsoon may have been initiated by the mid-Eocene (Lu et al., 2018).

Plio-Pleistocene glacial-interglacial to millennial monsoon variability has also been revealed by the loess sequences and borehole sediments in the Weihe Basin. The geochemical composition of the Weinan loess profile confirmed that high-frequency pulses of East Asian monsoon climate in the last two glaciations were linked to the climate of the North Atlantic region (Guo et al., 1996). In ad- dition, glacial-interglacial changes in paleotemperature and precipitation have been quantitatively reconstructed using carbon isotopes and biomarkers from the Weinan loess profile (Sun et al., 2012; Thomas et al., 2017; Tang et al., 2017; Wang et al., 2018). To obtain high-resolution information on paleoenvironmental changes in the region, core LYH-1 (1097 m) was drilled in a residual lake (namely Luyanghu) in the northern Weihe Basin. Sedimentological and geochemical proxies from the upper $220 \mathrm{~m}$ of the core revealed that significant changes with a range of fluviallacustrine-eolian depositional environments were persistent over the last 1 Myr (Rits et al., 2016, 2017), likely reflecting monsoon-induced orbital- to millennial-scale hydroclimatic changes. Nine short cores $(7-8 \mathrm{~m})$ were recently retrieved from the proposed drilling site in the Weihe Basin. These sedimentary records are mainly composed of fine-grained silts and comprise climatic signals with a high potential for resolving millennial monsoon variability since the last glaciation. Previous investigations clearly highlight the great potential of the sediments in the Weihe Basin for assessing the long-term trends and short-term variability of the Asian climate during the Cenozoic. Therefore, high-resolution and continuous reconstruction of the Cenozoic climate can be achieved by obtaining long and high-quality drill cores from the Weihe Basin's depocentre.

\section{Geophysical survey results}

High-resolution wide-angle and deep seismic refraction/reflection detection data suggest the presence of two depressions located in the western and eastern Weihe Basin (Liu et al., 2016; Cai, 2017; Li, 2018) (Fig. 3). The western depression (Huyi) is located between Zhouzhi and Huyi. Its southern boundary is the Qinling fault (F2), the northern boundary is the Weihe fault (F3), the eastern boundary is the Lintong-Chang' an fault (F4), and the western boundary is the Longxian-Qishan-Mazhao fault (F1). A $5218 \mathrm{~m}$ deep borehole (WS10) in the depocentre of the Huyi depression just penetrated into the late Eocene (Fig. 2b), suggesting the presence of a much thicker Cenozoic sediment package in the western depression. The thickness of unconsolidated sediments in the Huyi depression exceeds $6000 \mathrm{~m}$ based on time-depth conversion of two-way travel time at the base of the central depression of about $\sim 4-4.5 \mathrm{~s}$. The deep seismic reflection profile shows that there are six major stratigraphic interfaces. Note that the integrity of the Huyi depression is lost due to the cutting of an east-west fault at depth.

The eastern depression (Gushi) is located between Weinan and Dali (Fig. 4). Its southern boundary is the WeinanJingyang fault (F5), the Weinan pediment fault (F6), and the Huashan pediment fault (F7), and its northern boundary is the Kouzhen-Guanshan fault (F8) and the Shuangquan-Linyi fault (F9). This depression is oriented E-W in general, with a maximum N-S width of $38 \mathrm{~km}$. The Gushi depression is only 


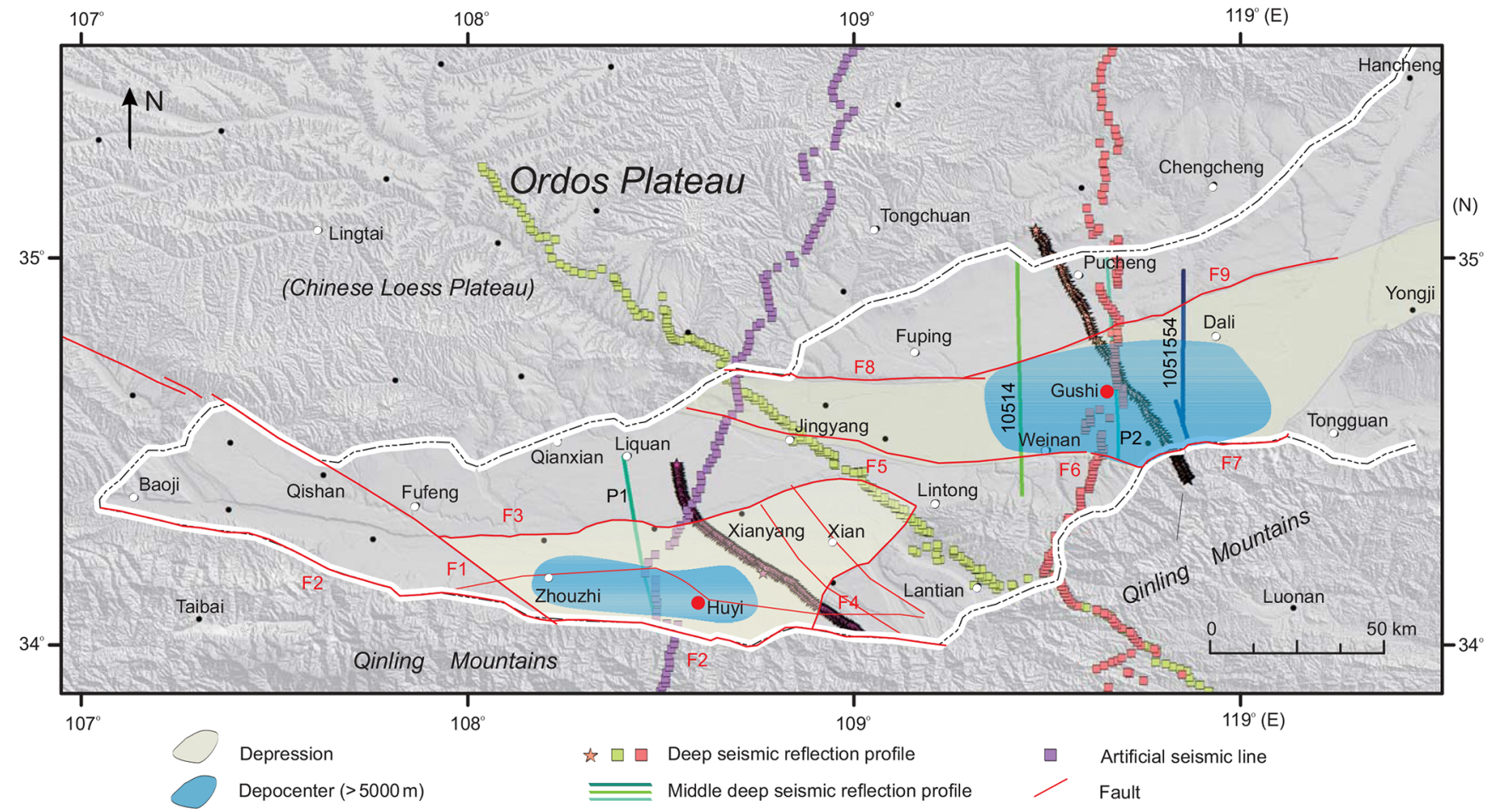

Figure 3. Geophysical surveys in the Weihe Basin.
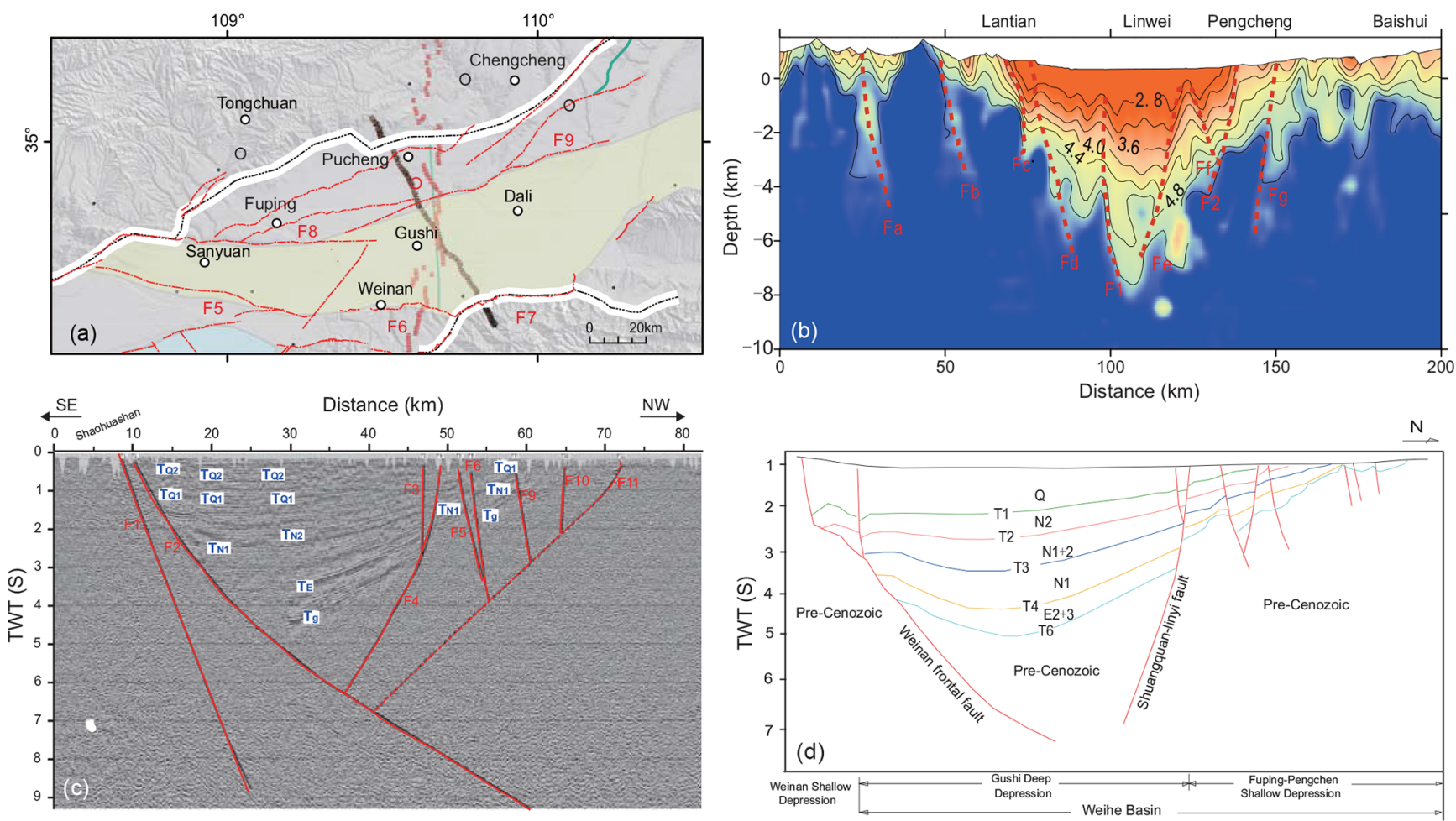

Figure 4. Geophysical survey interpretation of the eastern depression (Gushi) in the Weihe Basin. (a) Seismic survey lines in the eastern (Gushi) depression. (b) Wide-angle reflection results show that the depth of the Gushi depression can reach $\sim 7500 \mathrm{~m}$. (c) Deep seismic reflection profile. (d) Stratigraphical interpretation based on mid-deep seismic reflection data. 
surrounded by minor faults near its edges and lacks major faults crossing the depocentre (Fig. 4a). Wide-angle reflection shows that the thickness of acoustically well-stratified sediments deposited in the Gushi depression reaches up to $7500 \mathrm{~m}$ (Fig. 4b) based on a two-way travel time of $\sim 4.7 \mathrm{~s}$, and deep seismic reflection indicates the Cenozoic sediment may be deeper (Fig. 4c). The superimposed deep seismic reflection profile shows that there are six major stratigraphic interfaces, designated as T1-6, respectively (Fig. 4d). T1 indicates the basal boundary of the Quaternary, $\mathrm{T} 4$ denotes the basal boundary of the Neogene, and T6 may reflect the bedrock surface. The major geothermal and soluble helium gas resources were found within the Mio-Pliocene sediments $\left(\mathrm{N}_{1-2}\right)$ between T3 and T2, deposited under fluvial to shallow lacustrine conditions ( $\mathrm{Li}, 2018)$. Recently, the PetroChina Changqing Company drilled a $6535 \mathrm{~m}$ long borehole $16 \mathrm{~km}$ east to the depocentre of the Gushi depression down to the bedrock (for the location, see LC1 in Fig. 2), which revealed that the thickness of the Cenozoic strata is $\sim 6490 \mathrm{~m}$ and that the bedrock underlying the Cenozoic is Ordovician limestone.

\section{Workshop}

Based on promising survey information, scientists from the Institute of Earth Environment, Chinese Academy of Sciences, organized an international workshop on 15-18 October 2019 in Xi'an, which assembled 55 scientists from eight countries, representing various scientific domains, to specify the key objectives of the WBDP and the global significance of reconstructing Cenozoic climate evolution and tectonicclimate interaction. The morning session on the first day focused on the formation and evolution of the Weihe Basin from tectonic and sedimentary evidence, the Cenozoic depositional environments and paleoenvironmental evolution from the geophysical, outcrop, and drill core data, and the potential of the thick and continuous Cenozoic deposits in the Weihe Basin for paleoclimate research. The afternoon session focused on basin evolution, paleoclimatology, basinmountain coupling, sedimentary stratigraphic cycle correlation, and paleo- $\mathrm{CO}_{2}$ concentration reconstructions.

A field excursion was conducted on the second day. In the morning the team visited outcrops showcasing the Cenozoic lacustrine and eolian Red Clay-loess deposits exposed in the southern margin of the Weihe Basin (the northern slope of the Qinling Mountains). In the afternoon the team evaluated the proposed drill site in the Gushi depression in light of logistical and technical aspects. Group discussion resumed on the third day, during which participants thoroughly evaluated the drilling plan, scientific goals, and the technical feasibility of the envisioned WBDP. A detailed analytical programme was discussed in the workshop, including on-site downhole logging of physical parameters and monitoring of fluids and gases as well as off-site analy- ses including chronological (magnetostratigraphy, ${ }^{14} \mathrm{C}$ and burial ${ }^{26} \mathrm{Al} /{ }^{10} \mathrm{Be}$ dating), sedimentological (lithostratigraphy, structures, grain size), mineralogical/sediment provenancing (clay mineralogy, zircon ages), geochemical (major, minor, trace element geochemistry, stable $\mathrm{H}-\mathrm{C}-\mathrm{N}-\mathrm{O}$, and selected metal isotopic compositions), and biological (biomarkers along with compound specific $\mathrm{H}$ and $\mathrm{C}$ isotope compositions, pollen, plant silica, microchar) proxies.

The workshop concluded with clear research goals for tectonic, paleoclimatic, environmental, and geobiologic studies in the Weihe Basin and also formulated a management plan with timelines for the application of drilling and research proposals to the ICDP and other funding agencies. Three leading PIs (Zhisheng An, Peter Molnar, and Peizhen Zhang) will take overall responsibility for assembling and coordinating the WBDP. Five Co-PIs (John Dodson, Carmala Garzione, Hendrik Vogel, Mark Lever, and Youhong Sun) will lead and coordinate the multi-disciplinary and multi-national science team organized into five Working Groups. These five Working Groups were designed to optimize the workflow of on-site drilling and logging and off-site research of paleoclimate, tectonics, geomicrobiology, and data-model synthesis. The Synthesis Working Group will compare sedimentary records of different inland basins to decipher the long-term changes in the monsoon-arid environmental system and their dynamical links to regional tectonics and global climate change (e.g. Sun et al., 2009; Zhang et al., 2012; Liu et al., 2014). Moreover, integration of the WBDP with recently accomplished IODP projects (e.g. in the South China Sea, Bay of Bengal, Arabian Sea, and Japan Sea) surrounding the Asian continent will provide valuable insights into how these processes (tectonics, climate, the deep biosphere) were coupled during the Cenozoic.

As the main outcome of the workshop, participants proposed an integrated two-phase scientific drilling project to obtain as complete as possible sedimentary drill cores from the lacustrine and fluvial-lacustrine succession in the eastern Gushi depression of the Weihe Basin. WBDP Phase I will target the upper $\sim 3000 \mathrm{~m}$ thick sediment package to reconstruct orbital-to-millennial climate variability and to address the microbial community-environment relationship since the late Miocene $(\sim 10 \mathrm{Ma})$. WBDP-Phase II aims to produce $\mathrm{a} \sim 7500 \mathrm{~m}$ long continuous sedimentary record that spans the entire Cenozoic and with the Earth's most recent transition from hot greenhouse to cold icehouse climate conditions. Owing to the long time spans covered by both project phases, the WBDP will also allow us to provide answers to long-standing tectonic-climate interaction questions and help unravel the interplay of climate and tectonics in the evolution of angiosperms and the $\mathrm{C}_{4}$ photosynthetic pathway. In summary, the two-phase WBDP aims to decipher (1) onset and evolution of the Asian Paleomonsoon since the Eocene, (2) variability of atmospheric circulation and continental climate under warm periods with high atmospheric $\mathrm{CO}_{2}$ concentrations, (3) mountain-basin coupling processes, 
(4) Cenozoic tectonic-climate interactions, and (5) limits of life at depth in continental sediments.

\section{Participants of the workshop (alphabetical order)}

Zhisheng An (Institute of Earth Environment, Chinese Academy of Sciences, IEECAS), Paul Baker (Duke University, USA), Daniel Breecker (University of Texas at Austin, USA), Hong Chang (IEECAS), Feng Cheng (Rochester University, USA), Leon Clarke (Manchester Metropolitan University, UK), Steven Clemens (Brown University, USA), Jun Deng (China University of Geoscience, Beijing), John Dodson (University of Wollongong, Australia), Shuwen Dong (Nanjing University), Yunpeng Dong (Northwest University), Ying Dong (Xi' an Center of Geological Survey, CGS), Xiaonan Duan (Chinese Academy of Sciences), Robert Duce (Texas A \& M University, USA), Xijie Feng (Earthquake Administration of Shaanxi Province, China), Sherilyn Fritz (University of Nebraska, Lincoln, USA), Anlin Guo (Northwest University), Matthias Halisch (Leibniz Institute for Applied Geophysics, Germany), Huayu Lu (Nanjing University), Yuanbiao Hu (China University of Geoscience, Beijing), Zihan Huang (Nanjing University), Shugang Kang (IEECAS), Wenyuan Li (Xi' an Center of Geological Survey, CGS), Yu Liu (IEECAS), Jian Liu (Xi'an Center of Geological Survey, CGS), Xingxing Liu (IEECAS), Qingtian Lyu (Chinese Academy of Geological Sciences), Michael Meadows (University of Cape Town, South Africa), Xiaoke Qiang (IEECAS), Jianguo Ren (National Natural Science Foundation of China), Tada Ryuji (University of Tokyo, Japan), Pingping Sun (Xi'an Center of Geological Survey, CGS), Yougui Song (IEECAS), Youbin Sun (IEECAS), Youhong Sun (China University of Geoscience, Beijing), Hendrik Vogel (University Of Bern, Switzerland), Kexin Wang (Nanjing University), Pujun Wang (Jilin University), Sumin Wang (Nanjing Institute of Geography and limnology, CAS), Xulong Wang (IEECAS), Yichao Wang (Nanjing University), Thomas Wiersberg (GFZ German Research Centre for Geosciences, Germany), Jingsui Yang (Nanjing University), Yongkang Yin (Jilin University), Xuefeng Yu (IEECAS), Leping Yue (Northwest University), Christian Zeeden (Leibniz Institute for Applied Geophysics, Germany), Guowei Zhang (Northwest University), Hang Zhang (IEECAS), Hanzhi Zhang (Nanjing University), Maosheng Zhang (Xi' an Center of Geological Survey, CGS), Peizhen Zhang (Sun Yat-Sen University), Weijian Zhou (IEECAS), Xiulan Zong (IEECAS), and Li Ai (IEECAS).

Data availability. No data sets were used in this article.

Author contributions. ZA, PZ, YSu, and TW conceived and designed the workshop. YSu, LA, YSo, and HL organized the work- shop. ZA, YSo, HV, YSu, and LA prepared the paper, XF contributed to the geophysical figures and interpretation, HL contributed to the field trip of the workshop and previous investigation sections of the paper. PZ, JD, TW, HL, and XF discussed and revised the manuscript. The WBDP consortium provided intellectual input to the paper and workshop.

Competing interests. Author Thomas Wiersberg is a member of the editorial board of Scientific Drilling.

Acknowledgements. We would like to thank the Institute of Earth Environment, Chinese Academy of Sciences; State Key Laboratory of Loess and Quaternary Geology; Xi' an Center of Geological Survey; and Nanjing University for supporting the workshop. We thank Chengshan Wang, Shuwen Dong, and Rixiang Zhu for suggesting this workshop; Xiaoke Qiang and Hong Chang for organizing the field trip; and Youhong Sun and Yuanbiao Hu for the design of drilling engineering. Special thanks to ICDP for help in organizing this workshop.

Financial support. This workshop was funded by the External Cooperation Program (132B61KYSB20170005) and the Strategic Priority Research Program (XDB40000000) from the Chinese Academy of Sciences (CAS), State Key Laboratory of Loess and Quaternary Geology, and China Geological Survey (DD20190294).

Review statement. This paper was edited by Ulrich Harms and reviewed by Jef Vandenberghe and Steven Clemens.

\section{References}

An, Z.: Late Cenozoic Climate Change in Asia: Loess, Monsoon and Monsoon-arid Environment Evolution, Developments in $\mathrm{Pa}-$ leoenvironmental Research, Springer, Dordrecht, the Netherlands, 587 pp., 2014 ..

An, Z. and Ho, C.: New Magnetostratigraphic Dates of Lantian Homo erectus, Quaternary Res., 32, 213-221, https://doi.org/10.1016/0033-5894(89)90077-X, 1989.

An, Z., Kutzbach, J. E., Prell, W. L., and Porter, S. C.: Evolution of Asian monsoons and phased uplift of the HimayaTibtan plateau since Late Miocene times, Nature, 411, 62-66, https://doi.org/10.1038/35075035, 2001.

An, Z., Huang, Y., Liu, W., Guo, Z., Steven, C., Li, L., Warren, P., Ning, Y., Cai, Y., and Zhou, W.: Multiple expansions of $\mathrm{C}_{4}$ plant biomass in East Asia since $7 \mathrm{Ma}$ coupled with strengthened monsoon circulation, Geology, 33, 705-708, https://doi.org/10.1130/G21423.1, 2005.

An, Z., Wu, G., Li, J., Sun, Y., Liu, Y., Zhou, W., Cai, Y., Duan, A., Li, L., Mao, J., Cheng, H., Shi, Z., Tan, L., Yan, H., Ao, H., Chang, H., and Feng, J.: Global Monsoon Dynamics and Climate Change, Annu. Rev. Earth. Pl. Sc., 43, 29-77, https://doi.org/10.1146/annurev-earth-060313-054623, 2015. 
Cai, X.: Exploration and development of geothermal and two kinds of gas (water soluble gas and Helium) resources in Weihe Basin, Science Press, Beijing, China, 1-217, 2017.

Chen, W., Chen, J. X., and Yun, Q.: Report on the Geological Results of the Oil Survey in the Fenwei Basin. Third Survey Team 301 Unit, State geology administration of China, Xianyang, China, 1-112, 1977.

Dong, Y., Zhang, G., Neubauer, F., Liu, X., Genser, J., and Hauzenberger, C.: Tectonic evolution of the Qinling orogen, China: Review and synthesis, J. Asian Earth Sci., 41, 213-237, https://doi.org/10.1016/j.jseaes.2011.03.002, 2011.

Dupont-Nivet, G., Krijgsman, W., Langereis, C. G., Abels, H. A., Dai, S., and Fang, X.: Tibetan plateau aridification linked to global cooling at the Eocene-Oligocene transition, Nature, 445, 635-638, https://doi.org/10.1038/nature05516, 2007.

Fang, X., Garzione, C., Van der Voo, R., Li, J., and Fan, M.: Flexural subsidence by $29 \mathrm{Ma}$ on the NE edge of Tibet from the magnetostratigraphy of Linxia Basin, China, Earth Planet. Sc. Lett., 210, 545-560, https://doi.org/10.1016/S0012-821X(03)00142-0, 2003.

Fang, X., Fang, Y., Zan, J., Zhang, W., Song, C., Appel, E., Meng, Q., Miao, Y., Dai, S., Lu, Y., and Zhang, T.: Cenozoic magnetostratigraphy of the Xining Basin, NE Tibetan Plateau, and its constraints on paleontological, sedimentological and tectonomorphological evolution, Earth-Sci. Rev., 190, 460-485, https://doi.org/10.1016/j.earscirev.2019.01.021, 2019.

Flemming, H.-C. and Wuertz, S.: Bacteria and archaea on Earth and their abundance in biofilms, Nat. Rev. Microbiol. 17, 247-260, https://doi.org/10.1038/s41579-019-0158-9, 2019.

Guo, Z., Liu, T., Guiot, J., Wu, N., Lü, H., Han, J., Liu, J., and Gu, Z.: High frequency pulses of East Asian monsoon climate in the last two glaciations: link with the North Atlantic, Clim. Dynam., 12, 701-709, https://doi.org/10.1007/s003820050137, 1996.

Haywood, A. M., Dowsett, H. J., and Dolan, A. M.: Integrating geological archives and climate models for the mid-Pliocene warm period, Nat. Commun., 7, 10646, https://doi.org/10.1038/ncomms10646, 2016.

IPCC.: Climate change 2001: The scientific basis, in: Contribution of Working Group I to the Third Assessment Report of the Intergovernmental Panel on Climate Change, edited by: Houghton, J. T., Ding, Y., Griggs, D. J., Noguer, M., van der Linden, P. J., Dai, X., Maskell, K. and Johnson, C. A., Cambridge University Press, Cambridge, UK, 2001.

Ji, S., Nie, J., Lechler, A., Huntington, K. W., Heitmann, E. O., and Breecker, D. O.: A symmetrical $\mathrm{CO}_{2}$ peak and asymmetrical climate change during the middle Miocene, Earth Planet. Sc. Lett., 499, 134-144, https://doi.org/10.1016/j.epsl.2018.07.011, 2018.

Jia, L., Zhang, Y., and Huang, W.: The Cenozoic Group of Lantian, in: Institute of Vertebrate Paleontology and Paleoanthropology IVPP, edited by: Institute of Vertebrate Paleontology and Paleoanthropology (IVPP) of the Chinese Academy of Sciences, Proceedings of the field conference on the Cenozoic Group of Lantian, Shaanxi Province, 3-8 November 1964, Xian, China, Science Press, Beijing, China, 1-31, 1966.

Kaakinen, A., Sonninen, E., and Lunkka, J. P.: Stable isotope record in paleosol carbonates from the Chinese Loess Plateau: Implications for late Neogene paleoclimate and paleovegetation, Palaeogeogr. Palaeocl., 237, 359-369, https://doi.org/10.1016/j.palaeo.2005.12.011, 2006.
Kutzbach, J. E. and Behling, P.: Comparison of simulated changes of climate in Asia for two scenarios: Early Miocene to present, and present to future enhanced greenhouse, Global Planet. Change, 41, 157-165, https://doi.org/10.1016/j.gloplacha.2004.01.015, 2004.

Kutzbach, J. E., Prell, W., and Ruddiman, W. F.: Sensitivity of Eurasian climate to surface uplift of the Tibetan Plateau, J. Geol., 101, 177-190, available at: https://www.jstor.org/stable/ 30081146 (last access: 18 November 2020), 1993.

Li, J., Fang, X., Song, C., Pan, B., Ma, Y., and Yan, M.: Late Miocene-Quaternary rapid stepwise uplift of the NE Tibetan Plateau and its effects on climatic and environmental changes, Quaternary Res., 81, 400-423, https://doi.org/10.1016/j.yqres.2014.01.002, 2014.

Li, Y.: Helium accumulation conditions and resource prospects in Weihe Basin, China, Geological Publishing House, Beijing, China, 1-286, 2018.

Li, Z. C., Li, W. H., Li, Y. X., Li, Y. H., and Han, W.: Cenozoic stratigraphy and paleoenviroments in the Weihe area, Shaanxi Province, J. Stratigraphy, 40, 168-179, 2016.

Lin, A., Rao, G., and Yan, B.: Flexural fold structures and active faults in the northern-western Weihe Graben, central China, J. Asian Earth Sci., 114, 226-241, https://doi.org/10.1016/j.jseaes.2015.04.012, 2015.

Liu, J., Zhang, P., Lease, R. O., Zheng, D., Wan, J., Wang, W., and Zhang, H.: Eocene onset and late Miocene acceleration of Cenozoic intracontinental extension in the North Qinling range-Weihe graben: Insights from apatite fission track thermochronology, Tectonophysics, 584, 281-296, https://doi.org/10.1016/j.tecto.2012.01.025, 2013.

Liu, J., Chen, X., Shi, W., Chen, P., Zhang, Y., Hu, J., Dong, S., and Li, T.: Tectonically controlled evolution of the Yellow River drainage system in the Weihe region, North China: Constraints from sedimentation, mineralogy and geochemistry, J. Asian Earth Sci., 179, 350-364, https://doi.org/10.1016/j.jseaes.2019.05.008, 2019.

Liu, T., Ding, M., and Gao, F.: Cenozoic stratigraphic sections between Xi' an and Lantian, Chin. J. Geol., 4, 199-208, 1960.

Liu, W., Liu, Z., An, Z., Sun, J., Chang, H., Wang, N., Dong, J., and Wang, H.: Late Miocene episodic lakes in the arid Tarim Basin, western China, P. Nat. Acad. Sci. USA, 111, 16292, https://doi.org/10.1073/pnas.1410890111, 2014.

Liu, Z., Bai, Y., and Zhou, L.: Basin structure and hydrocarbon accumulation conditions of the Weihe Basin, Petro. Geol. Experi., 38, 584-591, 2016.

Lu, H., Zhang, H., Wang, Y., Zhao, L., Wang, H., Sun, W., and Zhang, H.: Cenozoic depositional sequence in the Weihe Basin (central China): a long-term record of Asian monsoon precipitation from the greenhouse to icehouse earth, Quaternary Sci., 38, 1057-1067, 2018.

Lu, H. Y., Wang, X. Y., and Li, L. P.: Aeolian sediment evidence that global cooling has driven late Cenozoic stepwise aridification in central Asia, Geol. Soci., Lon. Spec. Pub., 342, 29-44, https://doi.org/10.1144/SP342.4, 2010.

Maslin, M. A., Shultz, S., and Trauth, M. H.: A synthesis of the theories and concepts of early human evolution, Philos. T. Roy. Soc. B, 370, 20140064, https://doi.org/10.1098/rstb.2014.0064, 2015. 
Meng, Q. R.: Origin of the Qinling Mountains, Sci. Sin. Terrae, 47, 412-420, https://doi.org/10.1360/N072016-00422, 2017 (in Chinese).

Molnar, P. and Tapponnier, P.: Cenozoic tectonics of Asia effects of a continental collision, Science, 189, 419-426, https://doi.org/10.1126/science.189.4201.419, 1975.

Northrup, C. J., Royden, L. H., and Burchfiel, B. C.: Motion of the Pacific plate relative to Eurasia and its potential relation to Cenozoic extension along the eastern margin of Eurasia, Geology, 23, 719-722, https://doi.org/10.1130/00917613(1995)023<0719:Motppr>2.3.Co;2, 1995.

Passey, B. H., Ayliffe, L. K., Kaakinen, A., Zhang, Z., Eronen, J. T., Zhu, Y., Zhou, L., Cerling, T. E., and Fortelius, M.: Strengthened East Asian summer monsoons during a period of high-latitude warmth? Isotopic evidence from Mio-Pliocene fossil mammals and soil carbonates from northern China, Earth Planet. Sc. Lett., 277, 443-452, https://doi.org/10.1016/j.epsl.2008.11.008, 2009.

Peltzer, G. and Tapponnier, P.: Formation and evolution of strikeslip faults, rifts, and basins during the India-Asia collision-an experimental approach, J. Geophy. Res.-Sol. Ea., 93, 15085-15117, https://doi.org/10.1029/JB093iB12p15085, 1988.

Potts, R.: Hominin evolution in settings of strong environmental variability, Quaternary Sci. Rev., 73, 1-13, https://doi.org/10.1016/j.quascirev.2013.04.003, 2013.

Ramstein, G., Fluteau, F., Besse, J., and Joussaume, S.: Effect of orogeny, plate motion and land-sea distribution on Eurasian climate change over the past 30 million years, Nature, 386, 788793, https://doi.org/10.1038/386788a0, 1997.

RGS (Reginal Geological Survey): Regional Geology of Shaanxi Province, Shaanxi Province, Shanxi, Geological Publishing House, Beijing, China, 1-698, 1989.

Rits, D. S., Prins, M. A., Troelstra, S. R., van Balen, R. T., Zheng, Y., Beets, C. J., Wang, B., Li, X., Zhou, J., and Zheng, H.: Facies analysis of the Middle and Late Quaternary sediment infill of the northern Weihe Basin, Central China, J. Quaternary Sci., 31, 152-165, https://doi.org/10.1002/jqs.2853, 2016.

Rits, D. S., Beets, C. J., Prins, M. A., van Balen, R. T., Troelstra, S. R., Luo, C., Wang, B., Li, X., Zhou, J., and Zheng, H.: Geochemical characterization of the middle and late Pleistocene alluvial fan-dominated infill of the northern part of the Weihe Basin, Central China, Palaeogeogr. Palaeocl., 482, 57-69, https://doi.org/10.1016/j.palaeo.2017.05.030, 2017.

Schippers, A., Neretin, L. N., Kallmeyer, J., Ferdelman, T. G., Cragg, B. A., John Parkes, R., and Jørgensen, B. B.: Prokaryotic cells of the deep sub-seafloor biosphere identified as living bacteria, Nature, 433, 861-864, https://doi.org/10.1038/nature03302, 2005.

Shi, W., Chen, L., Chen, X., Cen, M., and Zhang, Y.: The Cenozoic tectonic evolution of the faulted basins in the northern margin of the Eastern Qinling Mountains, Central China: Constraints from fault kinematic analysis, J. Asian Earth Sci., 173, 204-224, https://doi.org/10.1016/j.jseaes.2019.01.018, 2019.

Shi, Y., Feng, X., Dai, W., Ren, J., Li, X., and Han, H.: Distribution and structural characteristics of the Xi' an Section of the Weihe Fault, Acta Seism. Sini., 21, 636-651, 2008.

Song, P., Teng, J., Zhang, X., Liu, Y., Si, X., Ma, X., Qiao, Y., and Dong, X.: Flyover Crustal Structures Beneath the Qinling Orogenic Belt and Its Tectonic Implications, J. Geophys. Res.-Sol.
Ea., 123, 6703-6718, https://doi.org/10.1029/2017jb015401, 2018.

Sun, J., Zhang, Z., and Zhang, L.: New evidence on the age of the Taklimakan Desert, Geology, 37, 159-162, https://doi.org/10.1130/G25338A.1, 2009.

Sun, J., Lü, T., Zhang, Z., Wang, X., and Liu, W.: Stepwise expansions of $\mathrm{C}_{4}$ biomass and enhanced seasonal precipitation and regional aridity during the Quaternary on the southern Chinese Loess Plateau, Quaternary Sci. Rev., 34, 57-65, https://doi.org/10.1016/j.quascirev.2011.12.007, 2012.

Tang, C., Yang, H., Dang, X., and Xie, S.: Comparison of paleotemperature reconstructions using microbial tetraether thermometers of the Chinese loess-paleosol sequence for the past 350000 years, Sci. China Earth Sci., 60, 1159-1170, https://doi.org/10.1007/s11430-016-9035-y, 2017.

Thomas, E. K., Clemens, S. C., Sun, Y. B., Huang, Y. S., Prell, W., Chen, G. S., Liu, Z. Y., and Loomis, S.: Midlatitude land surface temperature impacts the timing and structure of glacial maxima, Geophys. Res. Lett., 44, 984-992, https://doi.org/10.1002/2016gl071882, 2017.

Wang, B., Zheng, H., Wang, P., and He, Z.: The Cenozoic strata and depositional evolution of Weihe Basin: Progresses and problems, Adv. Earth Sci., 28, 1126-1135, 2013.

Wang, B., Zheng, H., He, Z., Wang, P., Kaakinen, A., and Zhou, X.: Middle Miocene eolian sediments on the southern Chinese Loess Plateau dated by magnetostratigraphy, Palaeogeogr. Palaeocl., 411, 257-266, https://doi.org/10.1016/j.palaeo.2014.07.007, 2014.

Wang, H., Lu, H., Zhao, L., Zhang, H., Lei, F., and Wang, Y.: Asian monsoon rainfall variation during the Pliocene forced by global temperature change, Nat. Commun., 10, 5272, https://doi.org/10.1038/s41467-019-13338-4, 2019.

Wang, Z., An, Z., Liu, Z., Qiang, X., Zhang, F., and Liu, W.: Hydroclimatic variability in loess $\delta \mathrm{D}$ wax records from the central Chinese Loess Plateau over the past $250 \mathrm{ka}$, J. Asian Earth Sci., 155, 49-57, https://doi.org/10.1016/j.jseaes.2017.11.008, 2018.

Westerhold, T., Marwan, N., Drury, A. J., Liebrand, D., Agnini, C., Anagnostou, E., Barnet, J. S. K., Bohaty, S. M., De Vleeschouwer, D., Florindo, F., Frederichs, T., Hodell, D. A., Holbourn, A. E., Kroon, D., Lauretano, V., Littler, K., Lourens, L. J., Lyle, M., Pälike, H., Röhl, U., Tian, J., Wilkens, R. H., Wilson, P. A., and Zachos, J. C.: An astronomically dated record of Earth's climate and its predictability over the last 66 million years, Science, 369, 1383, https://doi.org/10.1126/science.aba6853, 2020.

$\mathrm{Xu}$, S., Mi, N., Xu, M., Wang, L., Li, H., and Yu, D.: Crustal structures of the Weihe graben and its surroundings from receiver functions, Sci. China Earth Sci., 57, 372-378, https://doi.org/10.1007/s11430-013-4719-x, 2014.

Ye, H., Zhang, B. T., and Mao, F. Y.: The Cenozoic tectonic evolution of the great north china - 2 types of rifting and crustal necking in the great north china and their tectonic implications, Tectonophysics, 133, 217-227, https://doi.org/10.1016/00401951(87)90265-4, 1987.

Yin, A., Dang, Y.-Q., Zhang, M., Chen, X.-H., and McRivette, M. W.: Cenozoic tectonic evolution of the Qaidam basin and its surrounding regions (Part 3): Structural geology, sedimentation, and regional tectonic reconstruction, GSA Bull., 120, 847-876, https://doi.org/10.1130/B26232.1, 2008. 
Yue, L.: Magnetostratigraphical study of the loess section at Duanjiapo, Lantian, Shaanxi, Geol. Rev., 35, 479-488, 1989.

Yue, L., Heller, F., Qiu, Z., Zhang, L., Xie, G., Qiu, Z., and Zhang, Y.: Magnetostratigraphy and pavleo-environmental record of Tertiary deposits of Lanzhou Basin, Chin. Sci. Bull., 46, 770773, https://doi.org/10.1007/BF03187220, 2001.

Zachos, J., Pagani, M., Sloan, L., Thomas, E., and Billups, K.: Trends, rhythms, and aberrations in global climate $65 \mathrm{Ma}$ to present, Science, 292, 686-693, https://doi.org/10.1126/science.1059412, 2001.

Zhang, P., Wang, Q., and Ma, Z.: GPS velocity field and active crustal blocks of contemporary tectonic deformation in continental China, Earth Sci. Front., 9, 430-441, 2002.

Zhang, W., Appel, E., Fang, X., Song, C., and Cirpka, O.: Magnetostratigraphy of deep drilling core SG-1 in the western Qaidam Basin (NE Tibetan Plateau) and its tectonic implications, Quaternary Res., 78, 139-148, https://doi.org/10.1016/j.yqres.2012.03.011, 2012.

Zhang, Y. Q., Vergely, P., and Mercier, J.: Active faulting in and along the Qinling Range (China) inferred from spot imagery analysis and extrusion tectonics of south China, Tectonophysics, 243, 69-95, https://doi.org/10.1016/0040-1951(94)00192-C, 1995.

Zhang, Y. G., Pagani, M., Liu, Z., Bohaty, S. M., and Deconto, R. M.: A 40-million-year history of atmospheric $\mathrm{CO}_{2}$, Philos. T. Roc. Soc. A, 371, 20130096, https://doi.org/10.1098/rsta.2013.0096, 2013.
Zhao, L., Lu, H., and Tang, L.: Cenozoic palynological records and vegetation evolution in the Weihe Basin, Central China, Quaternary Sci., 38, 1083-1093, https://doi.org/10.11928/j.issn.10017410.2018.05.03, 2018.

Zhao, L., Lu, H., Wang, H., Meadows, M., Ma, C., Tang, L., Lei, F., and Zhang, H.: Vegetation dynamics in response to evolution of the Asian Monsoon in a warm world: Pollen evidence from the Weihe Basin, central China, Global Planet. Change, 193, 103269, https://doi.org/10.1016/j.gloplacha.2020.103269, 2020.

Zheng, H., An, Z., and Shaw, J.: New contributions to Chinese Plio-Pleistocene magnetostratigraphy, Phys. Earth Planet. Int., 70, 146-153, https://doi.org/10.1016/0031-9201(92)90177W, 1992.

Zhu, Z., Dennell, R., Huang, W., Wu, Y., Qiu, S., Yang, S., Rao, Z., Hou, Y., Xie, J., Han, J., and Ouyang, T.: Hominin occupation of the Chinese Loess Plateau since about 2.1 million years ago, Nature, 559, 608-612, https://doi.org/10.1038/s41586-018-0299-4, 2018.

Zhuo, H., Lu, H., Wang, S., Ahmad, K., Sun, W., Zhang, H., Yi, S., Li, Y., and Wang, X.: Chronology of newlydiscovered Paleolithic artifact assemblages in Lantian (Shaanxi province), central China, Quaternary Res., 86, 316-325, https://doi.org/10.1016/j.yqres.2016.08.008, 2016. 